\title{
Influence of Heat Treatment Regime on Corrosion Resistance of Clad Aluminium Alloy
}

\author{
Sylvia Kusmierczak ${ }^{1}$, Frantiska Peslova ${ }^{2}$, Natasa Naprstkova ${ }^{1}$ \\ ${ }^{1}$ Faculty of Mechanical Engineering, J. E. Purkyne University in Usti nad Labem. Pasteurova 3334/7, 40001 Usti nad \\ Labem. Czech Republic. E-mail: sylvia.kusmierczak@ujep.cz, natasa.naprstkova@ujep.cz \\ ${ }^{2}$ Faculty of Industrial Technologies, Alexander Dubček University of Trenčín. Ivana Krasku $491 / 3002001$ Púchov. \\ E-mail: frantiska.peslova@fpt.tnuni.sk
}

\begin{abstract}
Al-Cu-Mg based alloys are often used in the automotive industry. There are characterized by high strength characteristics but poor corrosion resistance, which appears to be problematic in this sector. The manufactured blanks of these alloys may be protected by some of the barrier protection methods, including cladding. Semifinished products made of these methods can be protected against corrosion by a thin layer of aluminium oxides called clad Durals. The surface layer creates a stable and durable $\mathrm{Al}_{2} \mathrm{O}_{3}$ layer, which provides corrosion resistance, which leads to an extended service life of the piece.

However, this type of protection is adversely affected by the effect of copper diffusion, which is dependent on the heat treatment mode of the alloy. Temperature and temperature hold are the main factors influencing the diffusion process. In the solution annealing of aluminium alloys, the temperature is in the range of $(470-500){ }^{\circ} \mathrm{C}$, resulting in intense diffusion processes at the inter phases interfacial.

The paper deals with the analysis of the influence of the heat treatment regime on the corrosion resistance of Al2024 alloy sheets (AlCu4Mg1 type alloy) provided with an Al1050 alloy clad coating on both sides in a corrosive salt mist environment in accordance with EN ISO 9227, which is supposed to have a positive effect on extending the service life of a car component.
\end{abstract}

Keywords: aluminium alloys, cladding, heat treatment, corrosion resistance, REM

\section{Introduction}

At present, aluminium alloys have without discussion an irreplaceable place in the world of technology. This is mainly due to excellent physical properties, which are complemented by corresponding technological, mechanical, and last but not least, corrosion properties [1, 2]. A wide range of semi-finished products from these alloys is made possible by the presence of alloying elements in combination with modification, inoculation, heat treatment, cold forming, eventually anodizing. [3-8]

Aluminium is a very reactive and easily oxidizable element, yet it behaves as a corrosion-resistant metal due to the protective effect of the passivation layer. This property is also evident in its alloys. The thickness of the oxide layer is usually in the range of $10^{-10} \mathrm{~m}$ to $10^{-6} \mathrm{~m}$ and is directly dependent on environmental conditions (presence of anions, cations, temperature, $\mathrm{pH}$ ). $[1,2]$ The influence of alloy elements on the corrosion stability of an aluminium alloy depends primarily on the environment, so the individual elements in aluminium alloys cannot be sorted by harmfulness. In general, the corrosion resistance increases with increasing amounts of aluminium. From the corrosion point of view, the aluminium content of copper alloys is decisive, which is related to the electrode potential of $\mathrm{Al}$ and $\mathrm{Cu}$. Copper is considered one of the most important elements in aluminium alloys because of its comparatively high solubility, and its effect of hardening, i.e. a process of solution annealing and aging. Therefore, Al alloys can be divided into two groups into alloys that contain and do not contain copper. $[1,4]$ Copper-free alloys - practically have the same chemical resistance as pure aluminium. Compared to pure $\mathrm{Al}$, however, they have significantly better mechanical properties, making them a suitable and used construction material. Copper-containing foundry alloys also have lower corrosion resistance, but due to the greater wall thickness of cast-ready products, corrosion attack is acceptable, especially when used in the atmosphere. [1,2] In special cases where there is a risk of pitting corrosion, cladding with a less noble alloy is used. The purpose of cladding is to electrochemically protect the base material from corrosion penetration into the depth. For example, $\mathrm{AlMg} 3$ and AlMgMn alloys are clad with AlZn1 alloy. $[1,9,10]$

Alloys for forming alloys containing copper, such as $\mathrm{AlCuMg}$ and $\mathrm{AlZnMgCu}$, are less resistant to aggressive chloride-containing environments as well as industrial environments. These alloys are among the oldest and most widely used aluminium alloys. They underwent a complex development from $\mathrm{Al}-\mathrm{Cu}$ binary alloys to complex alloys. [11, 12]

One sector where aluminium alloys have been booming over the past decade is the automotive industry. [3$5,13,14]$ Here, both foundry alloys and forming alloys based on $\mathrm{Al}-\mathrm{Cu}-\mathrm{Mg}$ are used. These in the context of aluminium alloys have a relatively high strength, but this is compensated by a relatively low corrosion resistance. $[1,2,11,12]$. Therefore, processes and technologies have been developed that create a barrier between the alloy surface and the environment, such as anodizing, varnishing, or coating. [1, 15-17]. With high demands on corrosion resistance, $\mathrm{AlCuMg}$ alloy is clad with pure aluminium, so-called clad aluminium. Metal cladding is a type of protective coating where the protective layer, in the form of a metal powder or foil, is bonded to the substrate by heat or pressure. $[1,9]$ Research on metal coating is important because this method of protection against corrosion and 
wear is generally very reliable and economically available. The coating parameters can be optimized for different types of products with respect to the environment to which they will be exposed. [1, 6-18] Aluminium cladding is done in two ways. After brushing and pickling, the cladding sheet is placed on a well-cleaned substrate (clad object), preheated and then hot rolled (380-450) ${ }^{\circ} \mathrm{C}$. Alternatively, the molten clad metal is poured onto the substrate, or the clad object is wetted into it. [1,9]

The aim of the article is to analyze the influence of the heat treatment mode on the corrosion resistance of EN AW-2024 alloy sheets (AlCu4Mg1 type alloy) provided with a clad layer of EN AW-1050 alloy coated on both sides in a corrosive in the salt mist environment in accordance with ČSN EN ISO 9227.

\section{Experimental material}

The alloy EN AW-2024 (AlCu4Mg1), which has poor corrosion resistance (Table 1), cladding with EN AW1050 (Table 2), was chosen for the experiment. The surface clad alloy layer has good corrosion resistance and is suitable for anodizing.

\section{Tab. 1 Chemical composition of alloy EN AW-2024}

\begin{tabular}{|c|c|c|c|c|c|c|c|c|c|}
\hline \multicolumn{10}{|c|}{ Chemical composition [wt. \%] } \\
\hline $\mathbf{C u}$ & $\mathbf{M g}$ & $\mathbf{F e}$ & $\mathbf{S i}$ & $\mathbf{T i}$ & $\mathbf{Z n}$ & $\mathbf{M n}$ & $\mathbf{C r}$ & total & Al \\
\hline $3.8-4.9$ & $1.2-1.8$ & $\max$. & $\max$. & $\max$. & $\max$. & $0.3-0.9$ & $\max$. & $\max$. & rest \\
& & 0.5 & 0.5 & 0.15 & 0.25 & & 0.1 & 0.15 & \\
\hline
\end{tabular}

Tab. 2 Chemical composition of alloy EN AW-1050

\begin{tabular}{|c|c|c|c|c|c|c|c|c|c|}
\hline \multicolumn{10}{|c|}{ Chemical composition [wt. \%] } \\
\hline Si & Fe & $\mathbf{C u}$ & $\mathbf{M n}$ & $\mathbf{M g}$ & $\mathbf{Z n}$ & $\mathbf{Z r}+\mathbf{T i}$ & $\mathbf{T i}$ & total & Al \\
\hline$\leq 0.25$ & $\leq 0.40$ & $\leq 0.05$ & $\leq 0.05$ & $\leq 0.05$ & $\leq 0.07$ & - & $\leq 0.05$ & $\leq 0.03$ & rest \\
\hline
\end{tabular}

For evaluation of corrosion resistance in the salt chamber, samples of EN AW-2024 alloy sheets with dimensions of 100x50 mm and thickness of $1.2 \mathrm{~mm}$ were divided into two groups. In the first group the full clad layer was preserved, in the second group approximately half of the clad layer was etched. 6 samples were prepared, one of which is a reference sample, without heat treatment. The remaining 5 samples were heat treated by recrystallization annealing at a temperature of $(495 \pm 5)^{\circ}$ $\mathrm{C}$ with varying residence times. The heat treatment process and sample labeling is shown in Table 3.

Tab. 3 Sample labeling and condition of heat treatment

\begin{tabular}{|c|c|c|c|c|c|}
\hline Sample labeling & Temperature & Holding time & Sample labeling & Temperature & Holding time \\
\hline $012-0-1,012-0-2$ & - & $0 \mathrm{~min}$ & $012-6-1,012-6-2$ & $495^{\circ} \mathrm{C}$ & $40 \mathrm{~min}$ \\
\hline $012-2-1,012-2-2$ & $495^{\circ} \mathrm{C}$ & $1 \mathrm{~min}$ & $012-8-1,012-8-2$ & $495^{\circ} \mathrm{C}$ & $50 \mathrm{~min}$ \\
\hline $012-4-1,012-4-2$ & $495^{\circ} \mathrm{C}$ & $30 \mathrm{~min}$ & $012-10-1,012-10-2$ & $495^{\circ} \mathrm{C}$ & $60 \mathrm{~min}$ \\
\hline
\end{tabular}

The etched samples were provided with adhesive tape at the bottom to prevent the surface from contacting the corrosive environment in the salt chamber.

Corrosive loading of the materials was carried out in the salt chamber in the SC450 chamber in accordance with ČSN EN ISO 9227. A series of etched surface samples was exposed to an aggressive salt chamber environment for only 1 week.

\section{Corrosion analysis}

After corrosion loading, samples of the experimental material were evaluated visually and microscopically. Corrosion products were removed (according to ČSN ISO 8407 ) with $5 \% \mathrm{HNO}_{3}$ solution.

From the visual evaluation of the samples of the first series (non-etched samples) it can be stated that with increasing holding time at the solution annealing temperature the corrosion resistance decreases.

In sheet metal samples, more significant corrosive degradation of the material occurred only in sample B - 012 $-10-1$ (Fig. 1), which was exposed to recrystallization temperature for $60 \mathrm{~min}$.

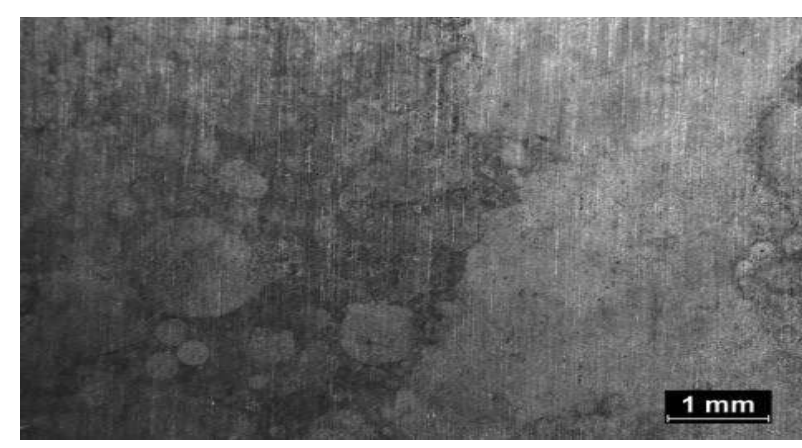

a) $B-012-0-1$

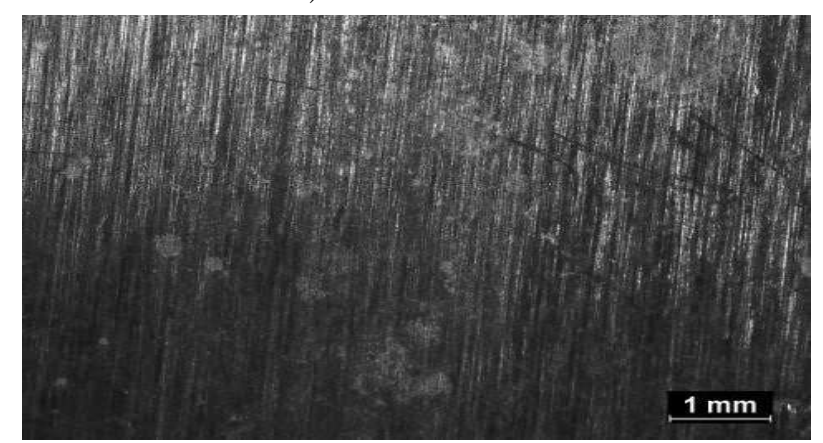

b) $B-012-2-1$ 


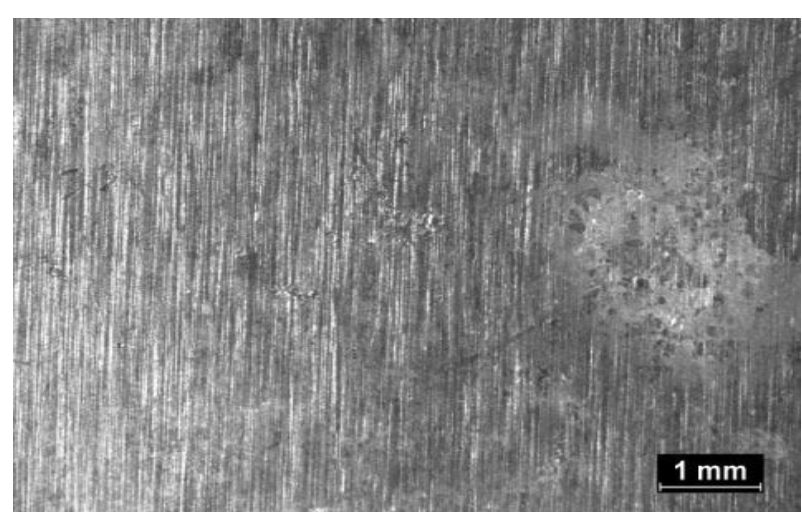

c) $B-012-4-1$

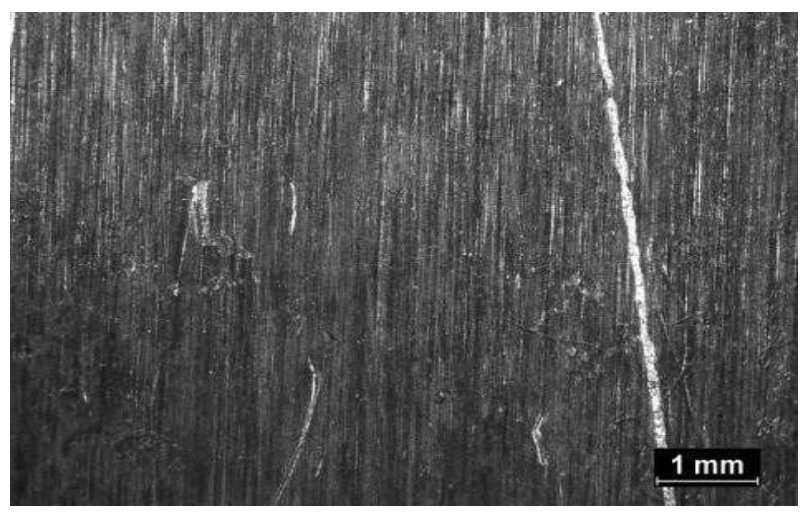

d) $B-012-6-1$

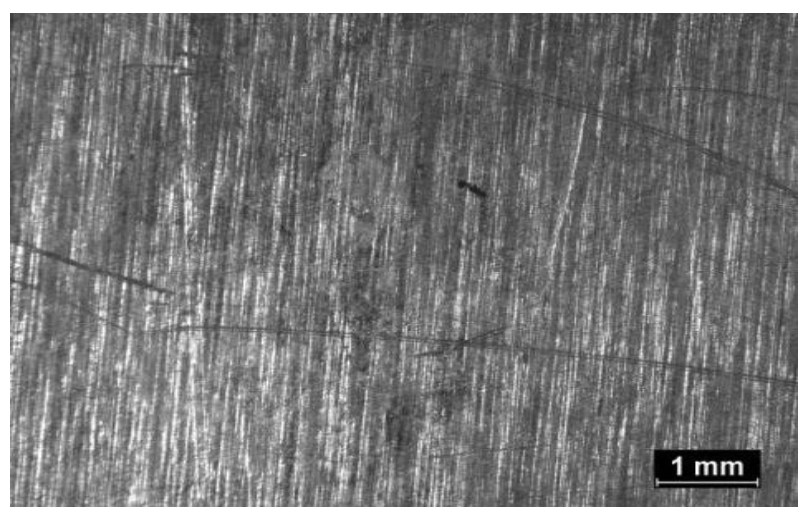

e) $B-012-8-1$

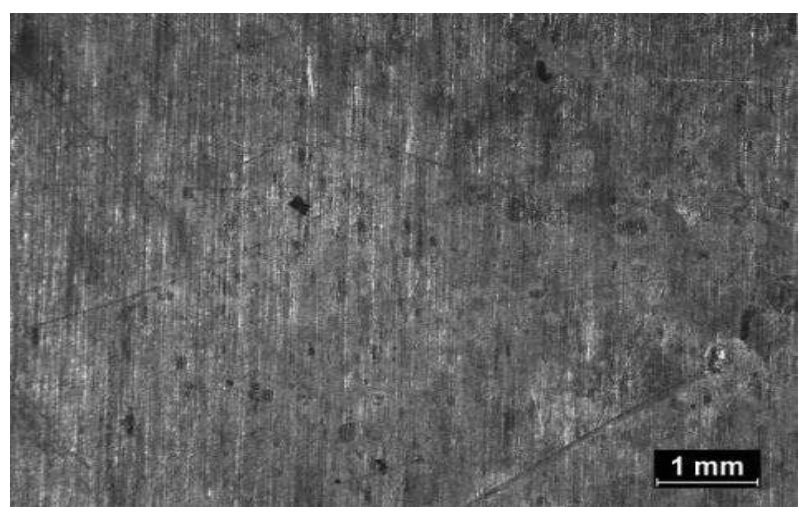

f) $B-012-10-1$

Fig. 1 Visual assessment of surface degradation, Series 1 , after removal of corrosion products

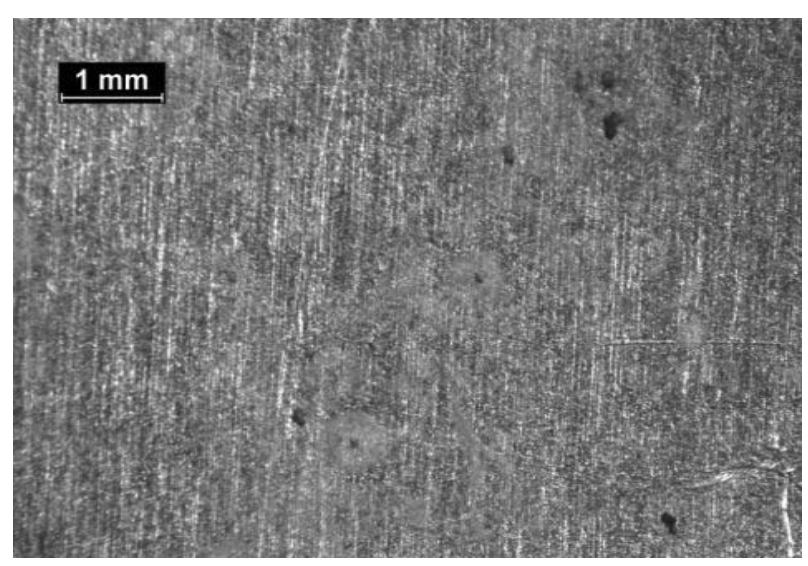

a) $B-012-0-2$

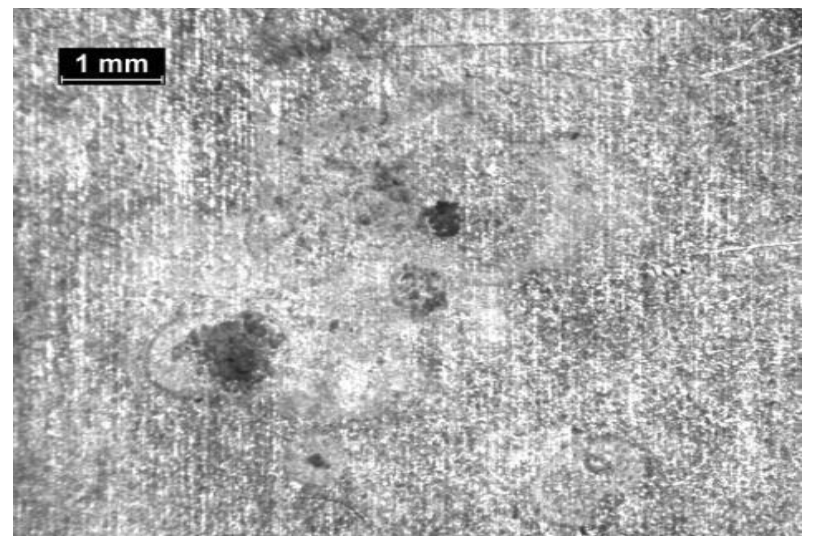

b) $B-012-2-2$

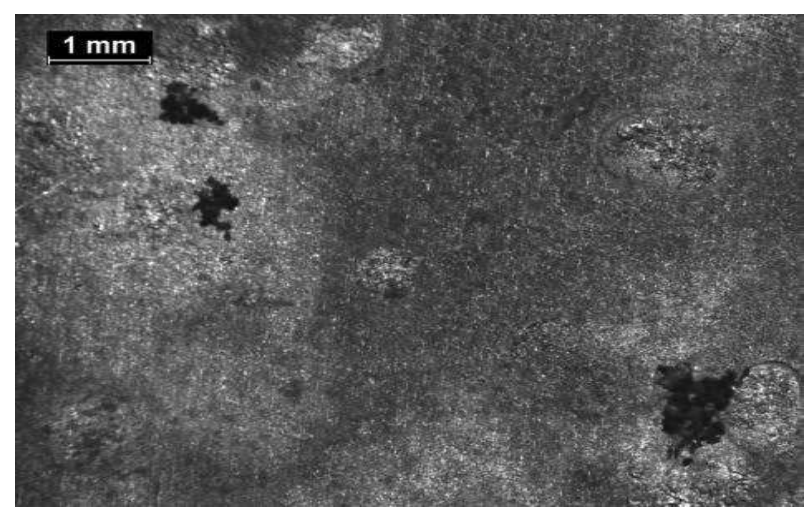

c) $B-012-4-2$

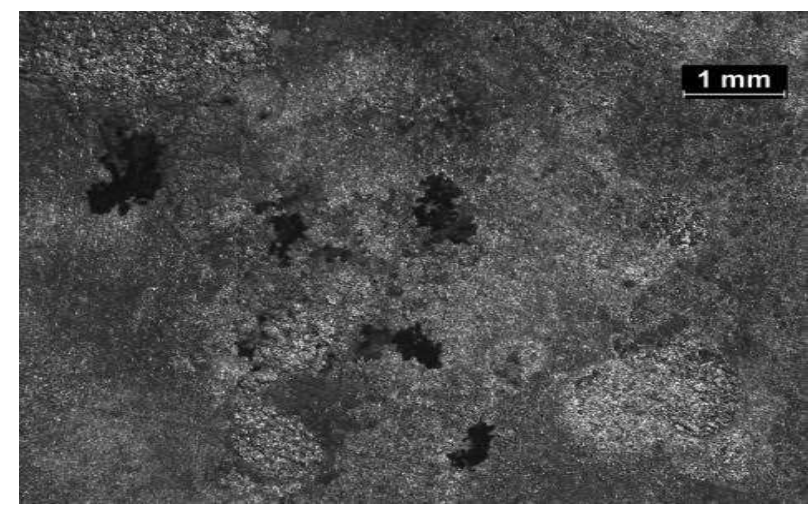

d) $B-012-6-2$ 


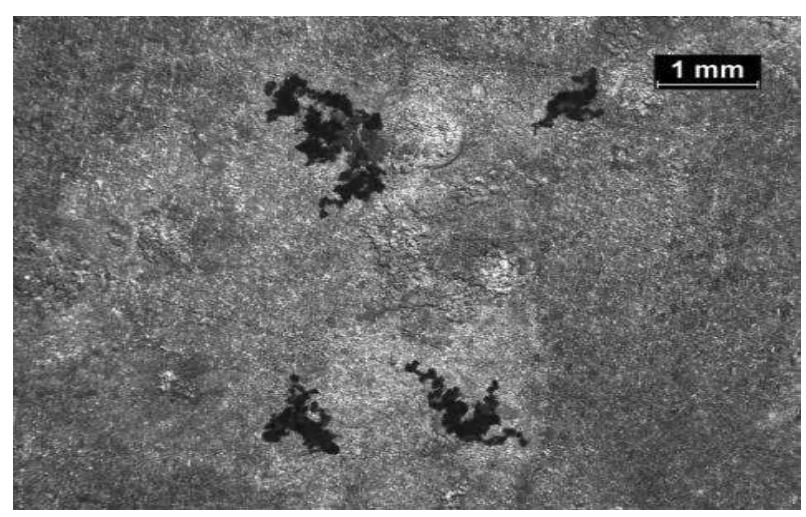

e) $B-012-8-2$

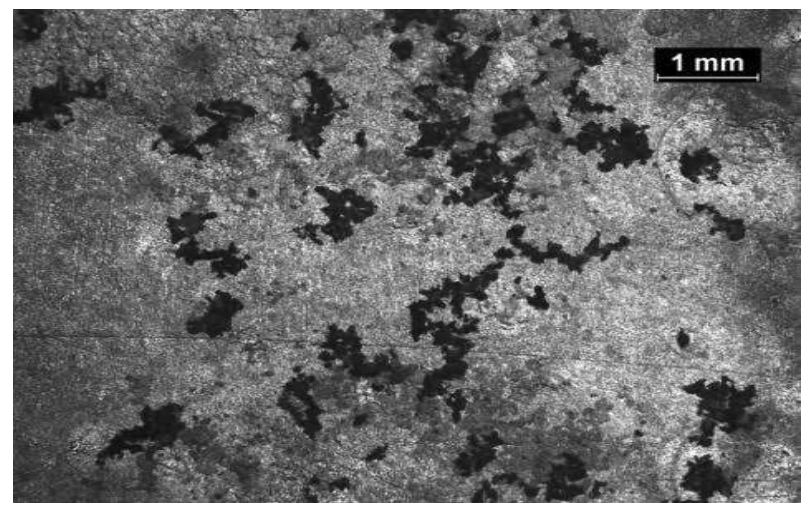

f) $B-012-10-2$

Fig. 2 Visual assessment of surface degradation, Series 2, after removal of corrosion products

The second set of samples was surface etched prior to the corrosion test. The etching was used to sensitize areas that may be depleted in copper or another element that contributes to corrosion resistance. For this reason, it can be assumed that there will be uneven corrosion attack in different locations. This effect was not observed in unetched samples.

The corrosion degradation trend of the second series (with etched surface) (Fig. 2) is similar to that of the first series. In sheet metal, significant corrosion initiation starts to occur in sample B - 012 - 4-2 (Fig. 2c), which was exposed to the temperature of recrystallization annealing for $33 \mathrm{~min}$. With increasing residence holding time at a given temperature, it is evident that the corrosion resistance has a decreasing tendency. Therefore, it can be stated that with increasing holding time at the solution annealing temperature $(495 \pm 5)^{\circ} \mathrm{C}$ the corrosion resistance of the sheets decreases.

The next step of the experiment was realization of microscopic analysis, which was preceded by metallographic preparation of samples. The samples were monitored using a Neophot 32 light microscope from Carl Zeiss. The image was converted by a CCD camera. NIS elements AR was used for further photo editing.

All etched specimens were microscopically evaluated in the transverse direction (emphasizing the clad layer), and locations that highlighted the corrosion degradation process in some way were selected for detailed observation (Fig. 3 a 4). The microstructure of the base material was characterized by intermetallic phases of different sizes and morpholondgy.

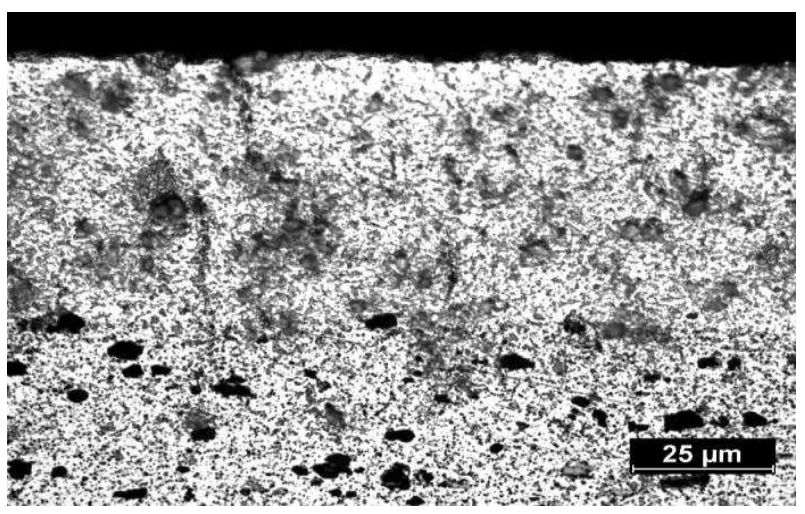

a) $B-012-0-1$

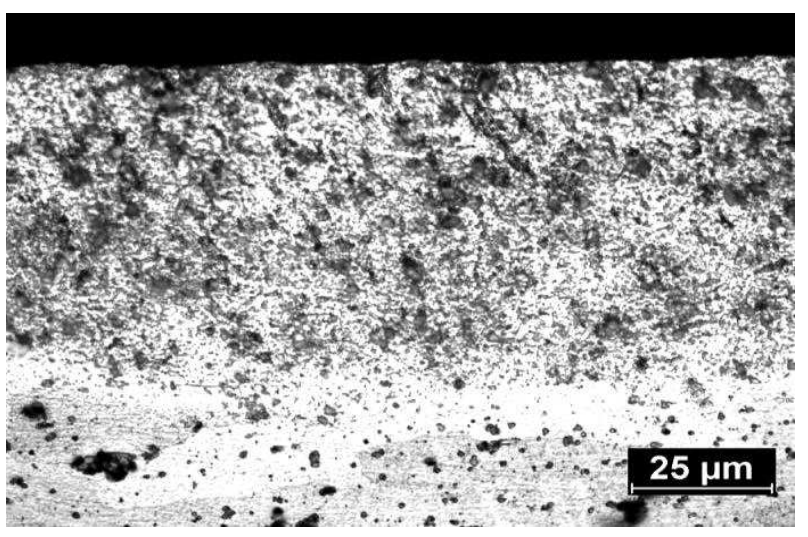

b) $B-012-2-1$

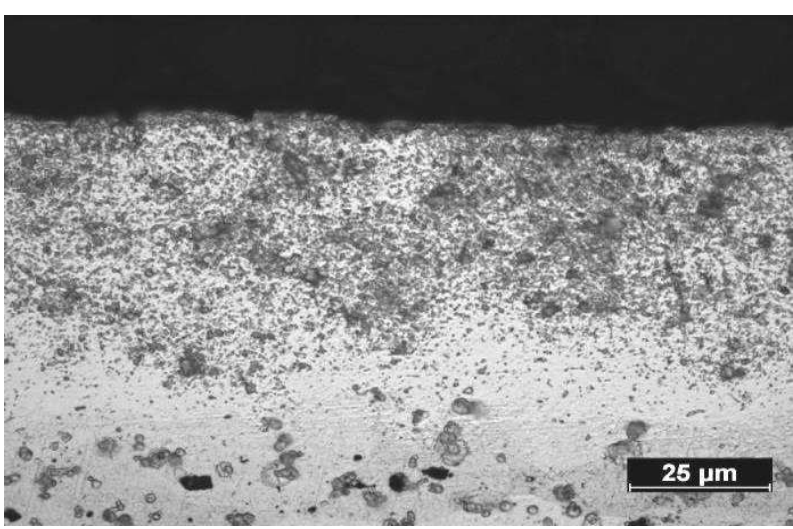

c) $B-012-4-1$

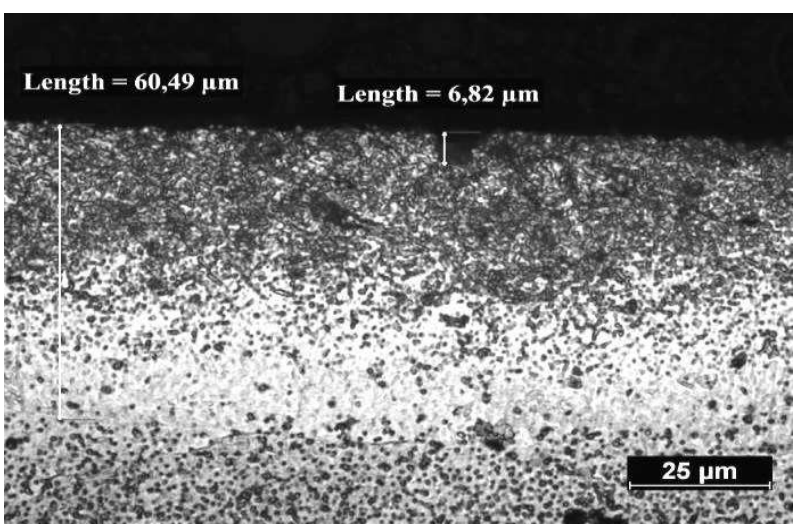

d) $B-012-6-1$ 


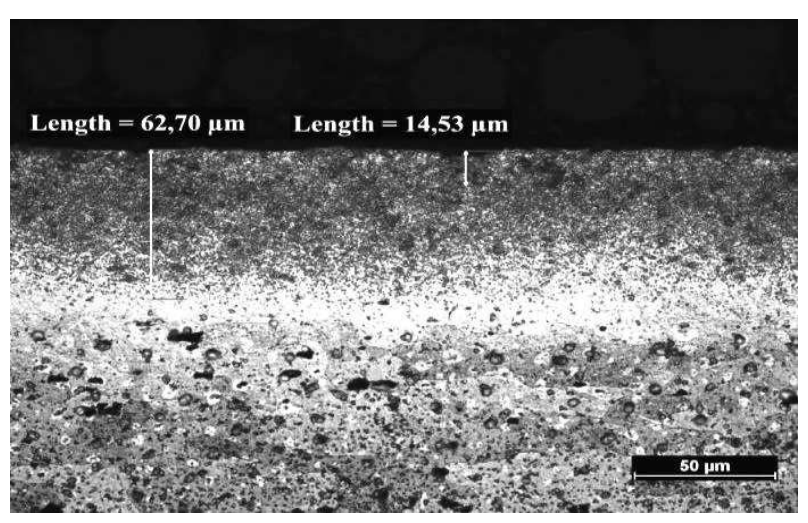

e) $B-012-8-1$

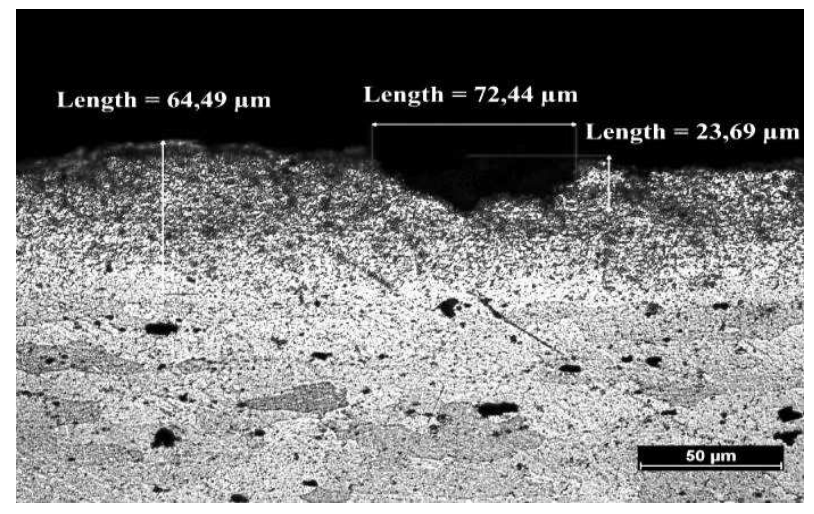

$$
\text { f) } B-012-10-1
$$

Fig. 3 Microscopic evaluation of layer degradation, Series 1 , after removal of corrosion products

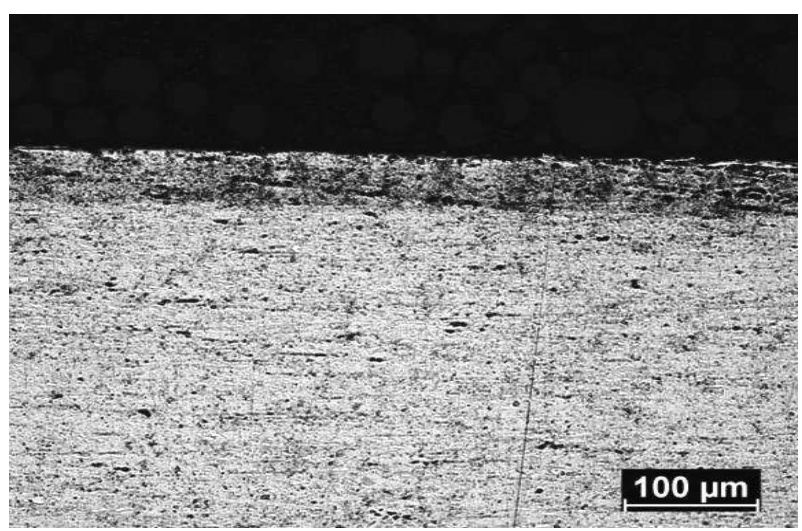

$$
\text { a) } B-012-0-2
$$

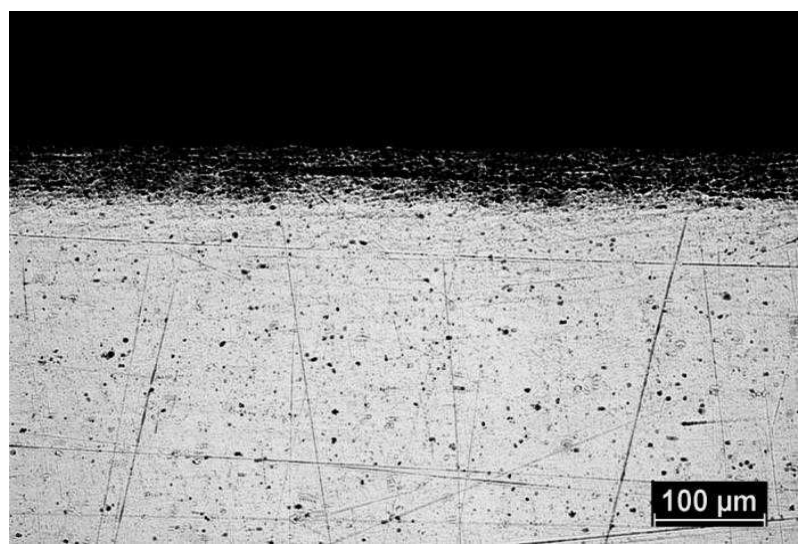

b) $B-012-2-2$

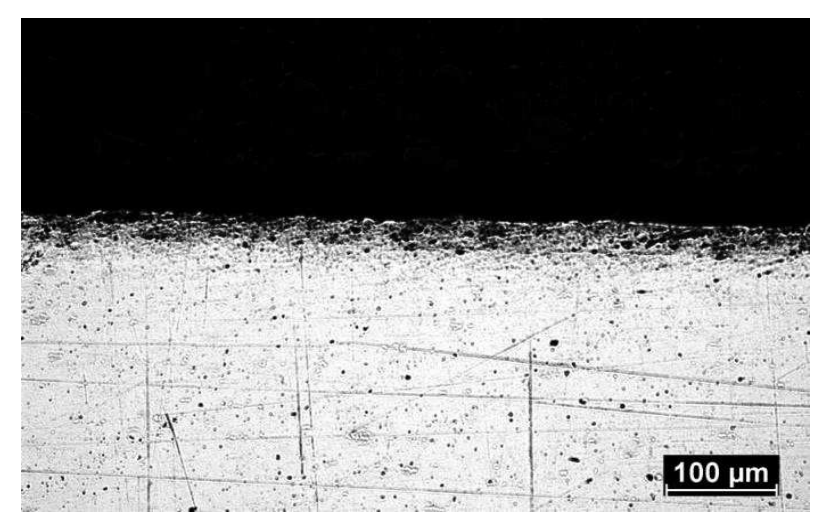

c) $B-012-4-2$

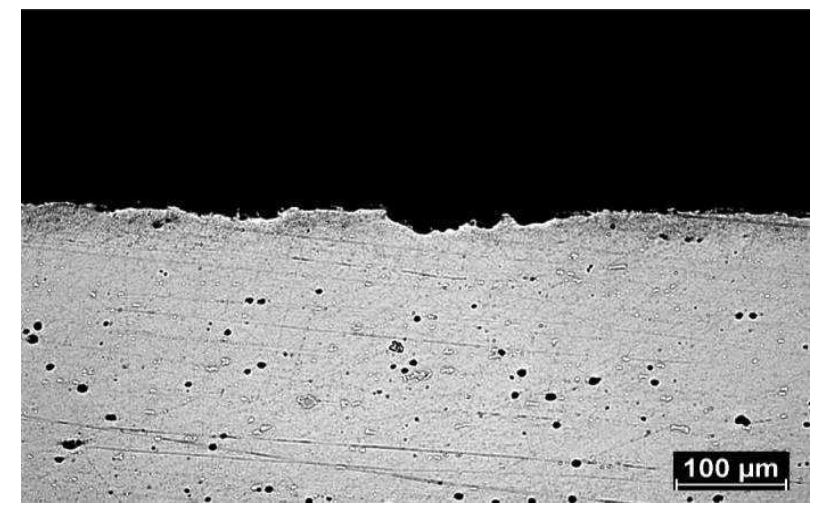

d) $B-012-6-2$

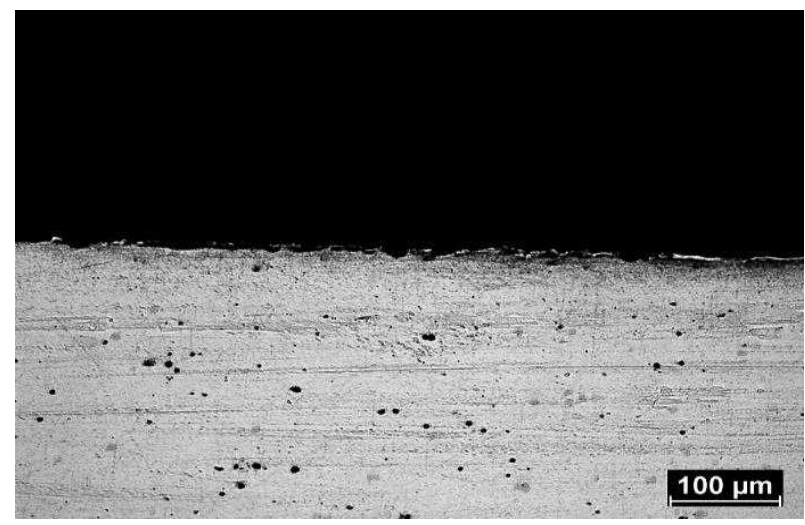

e) $B-012-8-2$

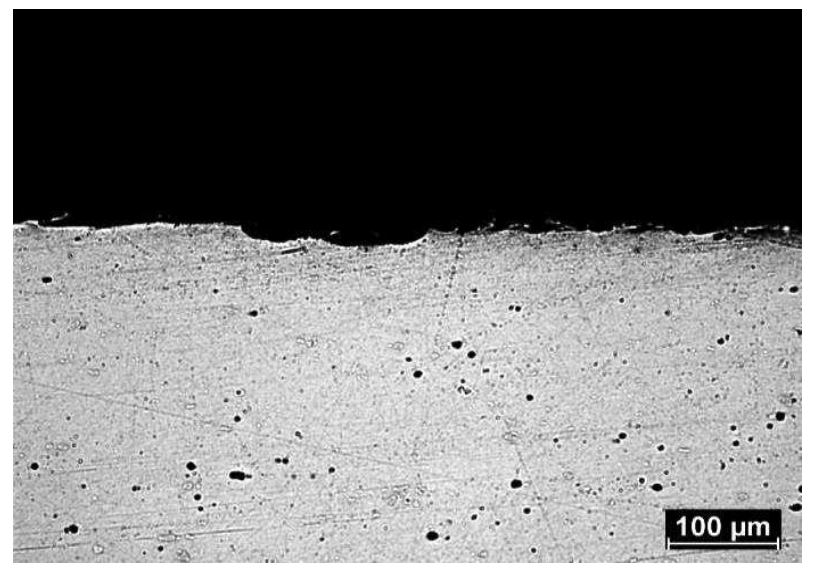

f) $B-012-10-2$

Fig. 4 Microscopic evaluation of layer degradation, Series 2, after removal of corrosion products 
The microstructures were observed for samples under the same corrosion conditions, but different solution annealing hold times. The structure, which was not heat treated, showed only the surface roughness obtained by the previous technology. A more significant change occurs with a hold time of 40 min for sample B - 012 - 6-1 (Fig. $3 \mathrm{~d}$ ), where the first occurrence of pitting corrosion was recorded. As the holding time increases at this temperature, pitting corrosion is progressive.

Analysis of the surface layer of the sheets of the second series showed (Fig. 4) that the etching failed to remove half of the clad layer (as originally planned), but the layer after the etching remained approximately the same size (with differences in tens of $\mu \mathrm{m}$ ). However, there was a significant damage to the homogeneity of this layer both on its surface and in volume. A significant number of voids have appeared in the layer, which have a positive effect on the propagation of corrosive action and corrosive degradation, which is significantly accelerated. Inequalities were observed on the surface, which further serve as an initiation of the spread of corrosion attack.

Microscopic evaluation of the etched cross-sections of the sheets showed that it was pitting corrosion. It can be stated that the holding time affects the character of the corrosively attacked surface. If some intermetallic surface particles are etched, these sites become the main initiators of the corrosion process.

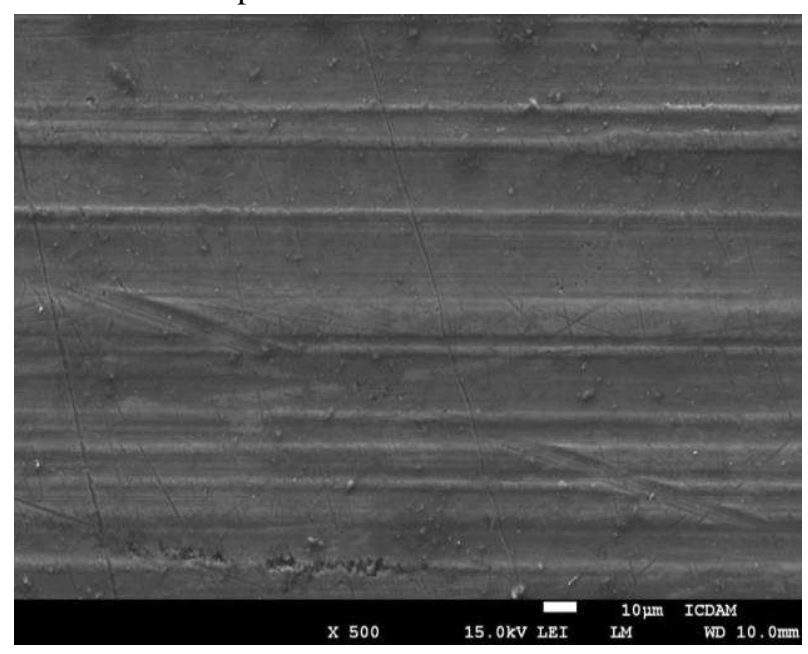

a) $B-012-0-2$

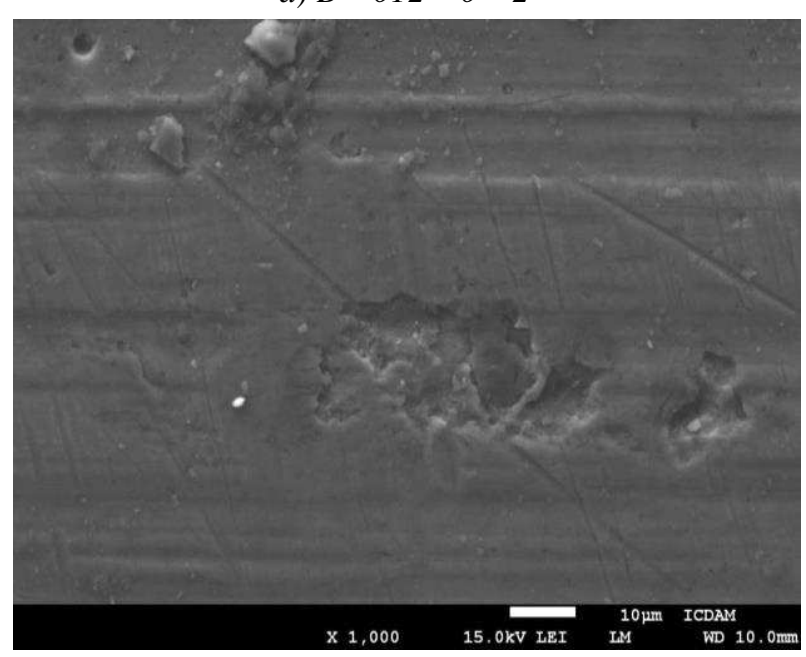

b) $B-012-2-2$

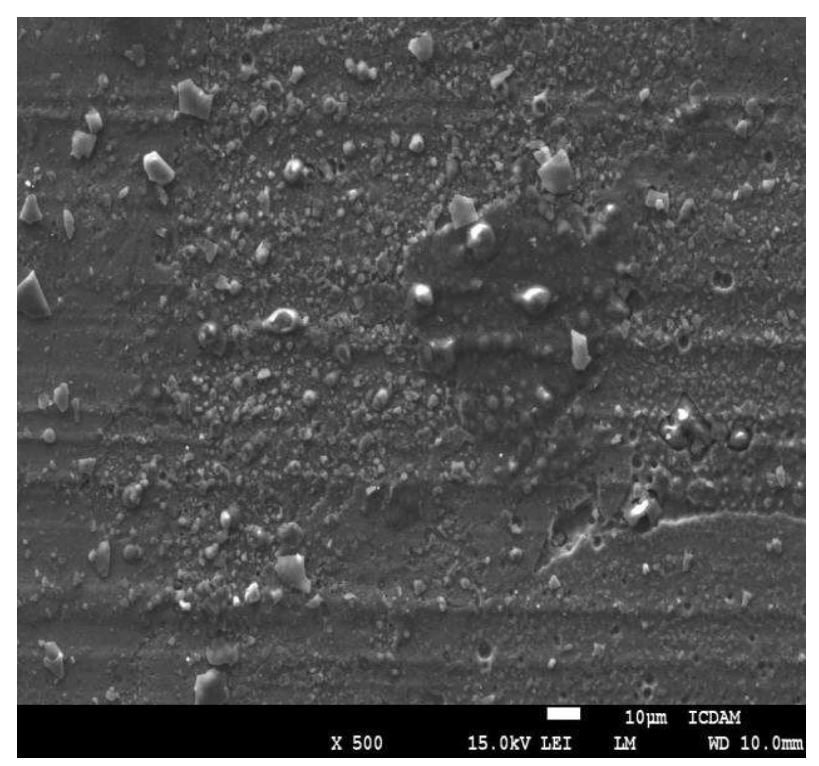

c) $B-012-4-2$

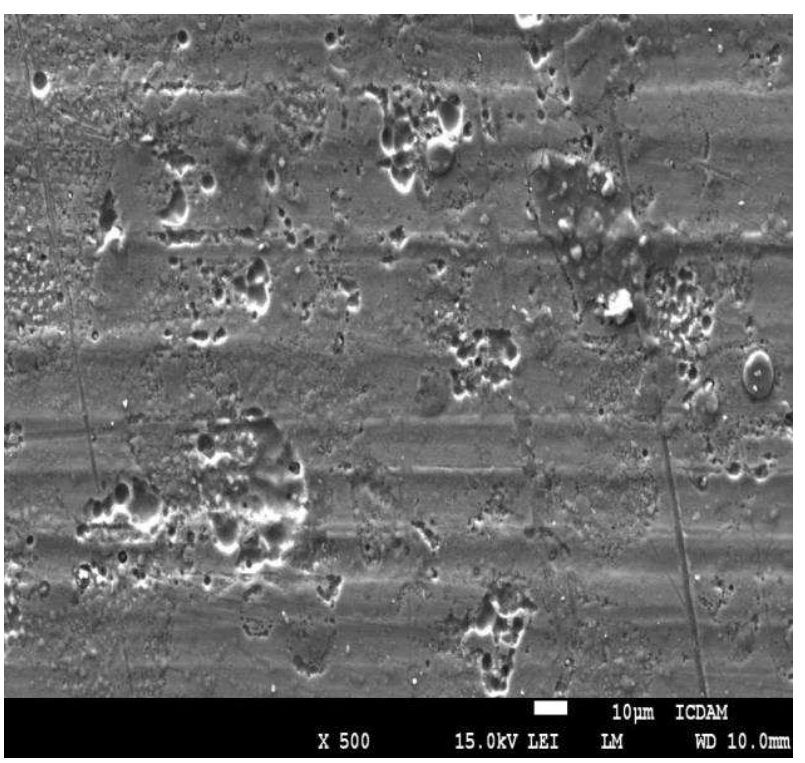

d) $B-012-6-2$

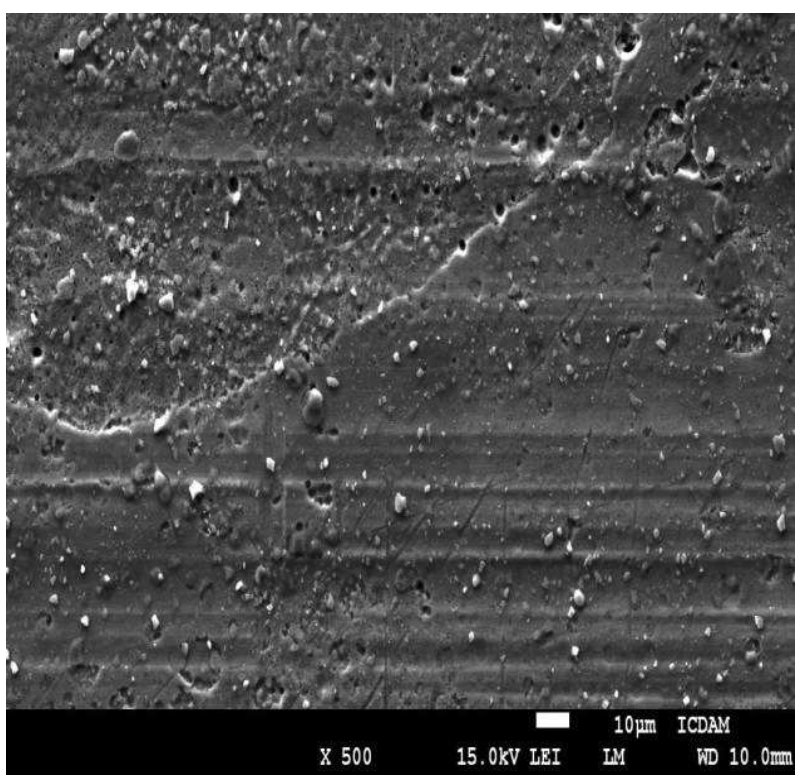

e) $B-012-8-2$ 


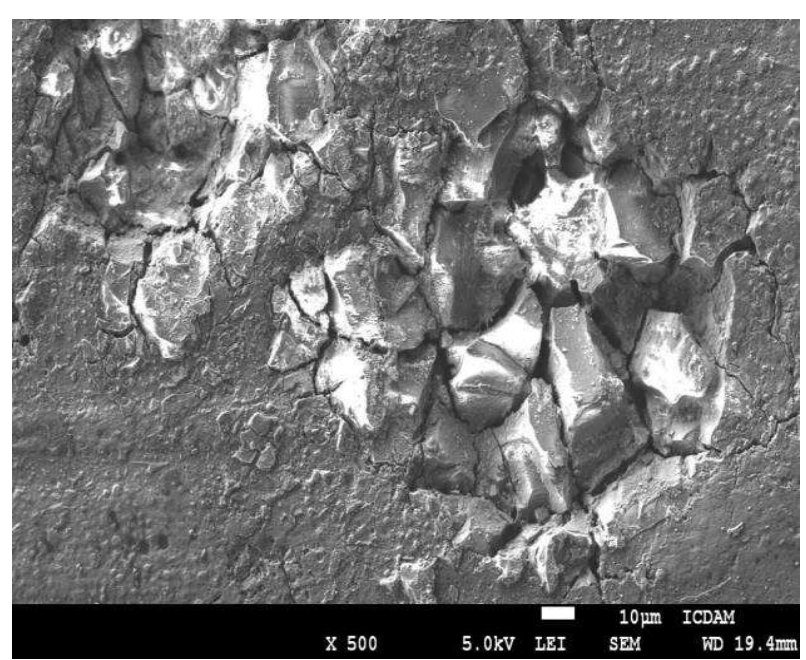

f) $B-012-10-2-$ detail

Fig. 5 State of material surface, REM

The microstructure obtained on an electron microscope shows the state of the sheet surface (Fig. 5). It can be seen from the observation that with increasing holding time at the solution annealing temperature $(495 \pm 5){ }^{\circ} \mathrm{C}$, the corrosion resistance of the sheets decreases due to the increasing copper content in the clad layer.

\section{Discussion}

A more detailed examination of the surface after the corrosion test showed that it was a pure aluminium cladding, which was influenced by the appearance of fine intermetallic phases, which were released during the corrosion process, creating cavities (pits). These were further developed to a greater depth by further corrosive environment. Sample B-012-10-2 (Fig. 5 e), which was exposed to the solution annealing temperature for 60 minutes, showed changes in surface stability that were locally differently susceptible to degradation failure. In some areas the structure was likely to become brittle, manifested as grain release (Fig. $5 \mathrm{f}$ ). At this point there is intercrystalline failure, where the corrosion process penetrates the bulk of the material at a higher rate.

\section{Conclusion}

The assumption that with increasing residence time at the solution annealing temperature also increased the copper content of the clad layer due to diffusion was correct. Microscopic examination of surface and subsurface structures showed a decreasing tendency of corrosion resistance as a function of residence time. The experiment confirms the theory of dependence of the diffusion process of copper on temperature and time.

In conclusion, based on literature and experimental findings, the corrosion resistance of the clad layer of the EN AW-1050 alloy will depend on:

- residence time at heat treatment temperature

- the purity of the cladding layer

- $\quad$ surface roughness after rolling

- thickness of the cladding layer
- cladding temperature

- accuracy of solution annealing temperature

- amount, size and distribution of intermetallic phases in given structures.

\section{Acknowledgement}

This contribution came from support of project $S G$ 4820715 2023-48 01 at UJEP.

This contribution came from support by the Slovak Grant Agency KEGA 007TnUAD - 4/2017, VEGA grant No. 1/0649/17, VEGA grant No. 1/0589/17.

\section{References}

[1] MICHNA, S. et al. (2007). Aluminium Materials and Technologies from $A$ to $Z$, Adin, ISBN 97880-89244-18-8.

[2] UHRÍČIK, M., PALČEK, P., CHALUPOVÁ, M., ORŠULOVÁ, T. (2017). The structure of the aluminium alloy and its influence on the fatigue properties. In: Manufacturing Technology, 17 (5), pp. 863-869.

[3] HREN, I., MICHNA, Š., DROZDYK, L., CAIS, J., MICHNOVÁ, L., SVOBODOVA, J., HODINÁŘ, L. (2018). Research of the influence on the modification of beryllium in $\mathrm{Al}-\mathrm{Si}$ alloy, In: Metallofizika i Noveishie Tekhnologii, 40 (12), pp. 1637-1647.

[4] MICHNA, Š., HREN, I., SVOBODOVÁ, J. (2019.) The research of the effect of high Fe content on $\mathrm{A} 1 \mathrm{Si} 9 \mathrm{NiCuMg} 0.5$ alloy, In: Manufacturing Technology, 19 (1), pp. 107-113.

[5] NAPRSTKOVA, N., KRAUS, P., STANCEKOVA, D. (2018). Calcium and its using for modification of ALSI7MG0.3 alloy from view of final microstructure and hardness, In: Engineering for Rural Development, 17, pp. 2003-2008.

[6] NÁPRSTKOVÁ, N., KRAUS, P., SVIANTEK, J., NGUYEN VAN, T. (2018). Influence of $\mathrm{Ca}, \mathrm{Sb}$ and heat treatment on $\mathrm{AlSi} 9 \mathrm{CuMnNi}$ alloy in frame of their properties from view of machining, In: MATEC Web of Conferences, 244, art. no. 02003 .

[7] PODPROCKÁ, R., BOLIBRUCHOVÁ, D. (2018). The role of manganese in the alloy based on Al-Si-Mg with higher iron content. In: Мапиfacturing Technology, 18 (4), pp. 650-654.

[8] SARYCHEV, V.D., IVANOV, Y.F., NEVSKII, S.A., SERENKOV, Y.S., VYSOTSKAYA, E.A., GROMOV, V.E. (2018). Mechanisms of nanoscale structure formation during electron beam treatment of silumin. In: IOP Conference Series: Materials Science and Engineering, 447 (1), art. no. 012061 .

[9] KORCZAK, P., PLONKA, B., LES̈NIAK, D., NOWAK, M., REMSAK, K., BOCZKAL, S. 
(2015). Studies on the magnesium alloys cladding in the plastic forming processes (die forging and extrusion) using as the clad layer corrosion resistant aluminum alloys. In: Magnesium Technology, 2015-January, pp. 257-262.

[10] CEPEDA-JIMÉNEZ, C.M., POZUELO, M., RUANO, O.A., CARREÑO, F. (2008). Influence of the thermomechanical processing on the fracture mechanisms of high strength aluminium/pure aluminium multilayer laminate materials. In: Materials Science and Engineering A, 490 (1-2), pp. 319-327.

[11] MÜLLER, M., VALÁŠEK, P. (2017). Research on aluminium alloy $\mathrm{AlCu} 4 \mathrm{Mg}$ surface machined by abrasive water jet. In: Manufacturing Technology, 17 (6), pp. 925-930.

[12] MÜLLER, M. (2017). Effects of Aluminium Microparticles and Surface Treatment of $\mathrm{AlCu} 4 \mathrm{Mg}$ on Mechanical Properties of Adhesive Bond Strength. In: Manufacturing Technology, February 2017, Vol. 17, No. 1, pp. 66-71, 2017, ISSN 1213-2489.

[13] KRAUS, P., NÁPRSTKOVÁ, N., JIROUNKOVÁ, K., CAIS, J., SVOBODOVÁ, J. (2018). Effect of heat treatment on the microstructure of the alloy A1Si7CrMnCu2.5. In: Manufacturing Technology, 18 (6), pp. 935-942.
[14] TILlOVÁ, E., CHALUPOVÁ, M., HURTALOVÁ, L., BONEK, M., DOBRZANSKI, L.A, (2011). Structural analysis of heat treated automotive cast alloy. In: Journal of Achievements in Materials and Manufacturing Engineering/JAMME, 47(1), 19-25.

[15] KALINCOVÁ, D., ŤTAVODOVÁ, M., JAKUBÉCZYOVÁ, D. (2018). Quality evaluation of the coatings and its influence on the wood machining tool wear. In: Manufacturing Technology, 18 (4), pp. 578-584.

[16] KAMENEVA, A., KICHIGIN, V. (2019). Corrosion, wear, and friction behavior of a number of multilayer two-, three- and multicomponent nitride coatings on different substrates, depending on the phase and elemental composition gradient. In: Applied Surface Science, 489, pp. 165-174.

[17] KUSMIERCZAK, S., SLAVIK, M. (2018). Analysis of Al-Si layer on steel sheet during thermo mechanical processing using microscopic methods. In: Manufacturing Technology, 18 (5), pp. 769-774.

[18] STANČEKOVÁ, D., ŠAJGALÍK, M., PETRU, J., NÁPRSTKOVÁ, N., BALAZ, P. (2015). Implementation of coating for failure elimination of dial gauges. In: METAL 2015, p. 24. 